\title{
Association between the Degree of Liver Cirrhosis Severity and Zinc Serum Level
}

\author{
Budi Yuwono $^{1}$, Ummi Maimunah ${ }^{2 *}$, Budi Widodo \\ ${ }^{1}$ Department of Internal Medicine, Faculty of Medicine, Universitas Airlangga - Dr. Soetomo General Hospital Surabaya, \\ Indonesia. \\ ${ }^{2}$ Division of Gastroentero-Hepatology, Department of Internal Medicine, Faculty of Medicine, Universitas Airlangga - Dr. \\ Soetomo General Hospital Surabaya, Indonesia.
}

\begin{abstract}
A B S T R A C T
Background: UImpaired liver function in LC (Liver Cirrhosis) can cause Zinc deficiency (Zn). One of the causes of Zn deficiency in LC is decreased albumin synthesis, where albumin is required as the main $\mathrm{Zn}$ binding protein in plasma. However, some studies of the severity of $\mathrm{LC}$ with $\mathrm{Zn}$ serum levels still provide controversial results.

Objective: To determine the association between the degree of LC severity and Zn serum level.

Methods: The subjects of this study were LC patients in Gastroentero-Hepatology Unit and Internal medicine in of Dr. Soetomo General Medicine Surabaya for three months. Diagnosis of LC was based on clinical examination according to criteria and other findings (ultrasound or endoscopy). The degree of LC severity was determined based on the CTP score (Child-Turcotte-Pugh). Serum Zn concentration was measured by atomic absorption spectrophotometry method. The research design used the cross-sectional method. The statistical test used was Spearman correlation.

Results: Forty-three patients fulfilled the study criteria. The subjects consisted of 27 males and 16 females with the mean age of $53.81 \pm 8.67$ years. Based on the CTP scores, we obtained CTP A of 4 patients, CTP B of 19 patients and CTP C of 20 patients . The mean of Zn serum level in CTP A, CTP B, and CTP C score was $58.3 \pm 19.6 \mu \mathrm{g} / \mathrm{dl}, 43.4 \pm 14.5 \mu \mathrm{g} / \mathrm{dl}$ and $31.6 \pm 10 \mu \mathrm{g} / \mathrm{dl}$ respectively. The result of the statistical test showed a significant correlation between LC severity and $\mathrm{Zn}$ serum level $(\mathrm{p}<0.05$ and $\mathrm{r}=-0.583)$.

Conclusion : The heavier the severity of LC, the lower $\mathrm{Zn}$ serum levels.
\end{abstract}

Keywords: Liver Cirrhosis, CTP Score, Zinc Serum Level

Correspondence: Ummi Maimunah

E-mail: ummima@gmail.com

Article history: • Received 30 December $2020 \bullet$ Received in revised form 08 January $2020 \bullet$ Accepted 27 January 2020

\section{INTRODUCTION}

Liver Cirrhosis (LC) is a progressive chronic liver disease with histopathologic features characterized by hepatocellular mass decline, hepatic architectural distortion, regenerative nodule formation, collapsed reticuline support tissue and connective tissue deposit(Bacon BR, 2008). Based on its functional status, $\mathrm{LC}$ is divided into decompensated LC and compensated LC. Decompensated $\mathrm{LC}$ is a condition if one or more of the following clinical signs and symptoms are present: jaundice, ascites, caput medusa, hepatic encephalopathy (HE), haemorrhagic bleeding due to esophageal varices (EV), hepatorenal syndrome, coagulopathy, and spontaneous bacterial peritonitis (SBP). Meanwhile, compensated SH does not have yet those clinical signs and symptoms (Kusumobroto HO, 2012, Heidelbaugh and Sherbondy, 2006).

Liver cirrhosis is one of the main causes of morbidity, mortality and a health problem that is difficult to overcome throughout the country. According to WHO (World Health Organization) in 2010, LH accounted for $1.8 \%$ of deaths in Europe or about 170,000 deaths per year (Blachier et al., 2013). According to reports from all Indonesian
Government General Hospital, LC prevalence was 3.5\% of all patients treated in the Internal Medicine wards or $47.4 \%$ of all treated liver disease. Comparison of LC patients between male and female was 1.6:1. The mean age of LC patients was 30-59 years with a peak at the age of 40-49 years (Nurdjanah S, 2009). Retrospective research at Dr. Soetomo General Hospital Surabaya Surabaya in 19971998 found $130 \mathrm{LC}$ patients or $14.7 \%$ of all patients treated in the Internal Medicine Room.

Malnutrition conditions are often found in LC, especially on decompensated LC. The prevalence of malnutrition in decompensated LC patients reached 60$78 \%$, whereas for compensated LC reached up to $25 \%$. LC patients with malnutrition have a high prevalence of morbidity and mortality. There are various factors that cause malnutrition in LC.

Malnutrition in LC may also lead to $\mathrm{Zn}$ deficiency. It is due to a change in gastrointestinal structural and function that cause in malnutrition resulting in malabsorption of nutrients including $\mathrm{Zn}$. A decrease in the ability of the small intestine to absorb $\mathrm{Zn}$ is due to villous atrophy occurring in malnutrition conditions. In addition, 
decreased production of bile, increased bacterial growth in the digestive tract and insufficiency of pancreatic secretion that occurs in malnutrition causes disrupted $\mathrm{Zn}$ absorption. Hypercatabolic conditions that occur in chronic disease (SH) can cause malnutrition due to increased $\beta$-adrenergic activity that stimulates the sympathetic nerves. It results in gluconeogenesis that reduces protein and fat. Hypercatabolic conditions require many $\mathrm{Zn}$ as co-enzymes in the process, this can lead to $\mathrm{Zn}$ deficiency. Malnutrition causes $\mathrm{Zn}$ in the muscle reserve will decrease. Anorexia as one of the causes of low nutritional intake including $\mathrm{Zn}$ is caused by delayed gastric emptying, rapid sensation of fullness and full feeling due to ascites. In addition, anorexia in chronic diseases such as LC is due to increased TNF- $\alpha$ and leptin.

Thedecreasing ofalbuminsynthetic orhypoalbuminemia can lead to Zn deficiency. Albumin synthesis occurs only in the liver with a synthesis rate of $194 \mathrm{mg} / \mathrm{kg} / \mathrm{day}(12-$ 25 grams/day). Normal conditions are when only $20-30 \%$ of hepatocytes produce albumin. Ineffective synthesis of albumin in LC leads to hypoalbumin. $\mathrm{Zn}$ in plasma is transported by albumin (60-70\%) and $\gamma-2$ macroglobulin (20-30\%) and a small amount are transported by transferrin and free amino acids. Hypoalbumin causes a $\mathrm{Zn}$ shift that bound to macromolecule ligands, thus he unbound zinc is easily filtered by the glomerulus, the condition may cause low serum Zn levels. Triwikatmani et al (2009) found that the lower serum levels of $\mathrm{Zn}$, the greater the level of $\mathrm{Zn}$ in urine (Triwikatmani C et al., 2009).

Physiologically, $\mathrm{Zn}$ is absorbed through two processes: $\mathrm{Zn}$ uptakes from the gastrointestinal lumen and $\mathrm{Zn}$ is transported from enterocytes to the circulatory system. $\mathrm{Zn}$ uptakes into enterocytes in free form $(\mathrm{Z}-\mathrm{Zn})$ or in a form bound to certain proteins especially those rich in histidine (Non-Specific Binding Protein-Zn / NSBP-Zn). Uptake free-Zn and NSBP-Zn in the intestinal lumen require a cysteine-rich intestinal protein (CRIP) protein. $\mathrm{Zn}$ deficiency occurs due to reduced income and absorption, increased spending, reduced utilization and increased demand.

\section{METHODS}

This study was an observational and analytic study with a cross-sectional design. This was conducted in Gastroenterol-Hepatology Unit and Internal medicine wards of Dr. Soetomo General Hospital Surabaya from April to June 2016. The population of this study were male and female of LC patients. The minimum sample size was 42 people. The independent variable of this study was the degree of liver cirrhosis severity. The dependent variable was the $\mathrm{Zn}$ serum level. The interfering variable was malnutrition and diuretic administration.

The inclusion criteria were male and female aged $\geq 18$ years that fulfilled LC diagnostic criteria, and willing to participate the research. The exclusion criteria were vomiting and diarrhea, paracentesis of ascites, sepsis, malignancy, bleeding. blood transfusion, DM, AIDS/ $\mathrm{HIV}$, EH, consuming supplements that contain $\mathrm{Zn}$, encephalopathy, and kidney disorders. The degree of severity of LC was determined based on the CTP score.
The results were presented in the form of tables. The data collected were processed using SPSS version 19. The data type was ordinal (categoric) for the degree of LC severity and ratio data (numerical) for $\mathrm{Zn}$ serum levels. One Way ANOVA test was performed on each category unit of CTP score. The association of the degree of LC severity and $\mathrm{Zn}$ serum level was tested using Pearson statistical test when the data were normally distributed, whereas the spearman statistic test was used if the data was not distributed normally.

\section{RESULTS}

Characteristics of the 43 subjects by age and sex were shown in Table 1 . The youngest was 36 years old and the oldest was 76 years old. The mean age of the subjects was $53.81 \pm 8.67$ years old and the most common age group was 51-60 years old. The majority of subjects was male as many as 27 patients $(62.8 \%)$ and female subjects were 16 patients $(37.3 \%)$.

Table 1. Characteristic of Subjects by Age and Sex

\begin{tabular}{cccc}
\hline Characteristic & Frequency & Mean \pm SD & Percentage \\
\hline Age (years old) & 43 & $53.8 \pm 8.67$ & - \\
$\leq 40$ & 3 & $36.66 \pm 0.19$ & $6.97 \%$ \\
$41-50$ & 13 & $46.38 \pm 6.25$ & $30.23 \%$ \\
$51-60$ & 19 & $56.61 \pm 7.19$ & $41.8 \%$ \\
$61-70$ & 7 & $63.00 \pm 5.56$ & $16.27 \%$ \\
$\geq 70$ & 1 & $76 \pm 0.00$ & $2.32 \%$ \\
\hline Sex & & - & \\
Male & 27 & & $62.8 \%$ \\
Female & 16 & & $37.2 \%$ \\
\hline
\end{tabular}

Clinical and laboratory results of LC patient samples consisted of ascites, encephalopathy, bilirubin, albumin, time of prothrombin, and $\mathrm{Zn}$ serum levels that were shown in Table 2.

Table 2. Clinical and laboratory results of LC patient samples

\begin{tabular}{lcccc}
\hline $\begin{array}{l}\text { Clinical and laboratory } \\
\text { examination }\end{array}$ & A & B & C & Percentage \\
\hline Ascites & & & & \\
$\quad$ None & 3 & - & - & $6.97 \%$ \\
$\quad$ Slight & 1 & 19 & 9 & $67.44 \%$ \\
$\quad$ Moderate & - & - & 11 & $25.58 \%$ \\
\hline $\begin{array}{l}\text { Enchephalopathy } \\
\quad \text { None }\end{array}$ & & & & \\
\hline $\begin{array}{l}\text { Bilinubin(mg/d) } \\
<2\end{array}$ & & 19 & 20 & $100 \%$ \\
$2-3$ & 3 & 12 & 2 & $39.53 \%$ \\
$>3$ & 1 & 7 & 7 & $34.88 \%$ \\
\hline & - & - & 11 & $25.58 \%$ \\
\hline
\end{tabular}

$\operatorname{Albumin}(\mathrm{mg} / \mathrm{dl})$ 


\begin{tabular}{lcccc}
$2.8-3.5$ & 2 & 10 & 2 & $32.55 \%$ \\
$<2.8$ & 1 & 9 & 18 & $65.11 \%$ \\
\hline $\begin{array}{l}\text { Protrombintime(2nd } \\
\text { increase) }\end{array}$ & & & & \\
$1-3$ & 3 & 17 & 2 & $51.15 \%$ \\
$4-6$ & 1 & 1 & 4 & $13.93 \%$ \\
$>6$ & - & 1 & 14 & $34.88 \%$ \\
\hline
\end{tabular}

Clinical examination obtained the majority of samples have the characteristics of slight ascites of 30 patients $(69.8 \%)$. Meanwhile, moderate/severe ascites were found in 11 patients $(25.6 \%)$ and two patients have not ascites $(4.7 \%)$. The encephalopathy characteristic for all samples was not obtained $(100 \%)$ because the criteria of encephalopathy were from stage 1 to 4 .

\section{Level of Meaning and Strength Association between the Degree of LC Severity and Zinc serum level}

Before analyzing the correlation between the degree of LC severity based on CTP scores and serum $\mathrm{Zn}$ values, then the test on the data of $\mathrm{Zn}$ serum level for each CTP score was performed. Normality test for the distribution of $\mathrm{Zn}$ serum level in 43 patients was using Shapiro Wilks test. The result of normality test of Zn serum level for each CTP score was shown in table 3.

Table 3. Normality Test

\begin{tabular}{ccc}
\hline Category & P value & Description \\
\hline CTP A & 0.121 & Normal \\
CTP B & 0.361 & Normal \\
CTP C & 0.094 & Normal \\
\hline
\end{tabular}

The result of normality test of Zn serum level for each CTP score obtained the p-value which was bigger than the error level $(>0.05)$. It meant that the data distribution of $\mathrm{Zn}$ serum level for each CTP score was distributed normally, then the statistical test used was One Way ANOVA parametric test. The statistical test of $\mathrm{Zn}$ serum level used the One Way ANOVA parametric method because the degree of LC severity based on CTP score has more than 2 categories. The differences of $\mathrm{Zn}$ serum levels on each CTP score were shown in Table 4.

Table 4. The Analysis Results of Zn serum levels on each CTP score

\begin{tabular}{lccc}
\hline & & Zn Serum Level & \\
CTPScore & $\mathrm{n}$ & Mean \pm SD & P value \\
\hline \hline CTP A & 4 & $58.3 \pm 19.6$ & \\
CTP B & 19 & $43.4 \pm 14.6$ & 0.001 \\
CTP C & 20 & $31.6 \pm 10.1$ & \\
\hline
\end{tabular}

The statistic result of $\mathrm{Zn}$ serum level on LC patients using One Way ANOVA test showed a significant difference. The lowest level of serum $\mathrm{Zn}$ was for the severity of CTP $\mathrm{C}$, while the highest was CTP A. This result showed the opposite relationship; the greater the degree of LC severity based on the CTP score, the lower the Zn serum level.

Before the correlation analysis between CTP scores with
Zn serum level was performed, we tested the distribution of data of both variables. Normality test was done using Kolmogorov-Smirnov test. The result of normality test of data distribution was shown in table 5 .

Table 5. Normality Test of CTP score and Zn Serum Level

\begin{tabular}{lcl}
\hline \multicolumn{1}{c}{ Data } & P value & Description \\
\hline CTPscore & 0.002 & Not normal \\
Znserumlevel & 0.028 & Not normal \\
\hline
\end{tabular}

The result of the distribution test of CTP scores with $\mathrm{Zn}$ serum level using the kolmogorov-Smirnov obtained p-value of 0.002 and 0.028 . It was concluded that the data of CTP score and Zn serum level was not distributed normally. The correlation test result between CTP scores and $\mathrm{Zn}$ serum levels using rank spearman correlation was shown in table 6 .

Tabel 6. The correlation test result between CTP scores and $\mathrm{Zn}$ serum levels

\begin{tabular}{ccccc}
\hline $\begin{array}{c}\text { CTP } \\
\text { scores }\end{array}$ & $\mathrm{n}$ & $\begin{array}{c}\text { Znserumlevel } \\
(\mathrm{ug} / \mathrm{dl})\end{array}$ & $\begin{array}{c}\mathrm{P} \\
\text { value }\end{array}$ & $\begin{array}{c}\text { Comelation } \\
\text { coefficient(r) }\end{array}$ \\
\hline \hline $\mathrm{A}$ & 4 & $58 \pm 19.6$ & & \\
$\mathrm{~B}$ & 19 & $43.4 \pm 14.6$ & 0.000 & -0.583 \\
$\mathrm{C}$ & 20 & $31.6 \pm 10.1$ & & \\
\hline \hline
\end{tabular}

We obtained correlation coefficient value of -0.583 . It meant that the correlation was negative with moderate correlation category. The value of this analysis was 0.000 , which was smaller than the 5\% significance level. Thus it was concluded that there was a significant negative correlation between CTP score and Zn serum level. The negative value meant the heavier (the worse) CTP score, the lower $\mathrm{Zn}$ serum values.

\section{DISCUSSION}

The degree of LC severity is classified as severe in liver dysfunction. The modification of Child Turcotte Pugh (CTP) criteria can still be used. The first score used was a child score with parameters of albumin, bilirubin, the presence or absence of ascites, EH and nutritional status. Pugh replaced the nutritional status in 1972 with the prothrombin period (Durand and Valla, 2005). The results of this study were grouped by the degree of LC severity by using CTP scores. We obtained CTP A of 4 patients $(9.3 \%)$, CTP B score of 19 patients $(44.2 \%)$ and CTP C score of 20 patients $(46,5 \%)$. The study of Somi et al (2007) on nutritional status and level of trace element (Fe, $\mathrm{Cu}$ and $\mathrm{Zn}$ ) of $60 \mathrm{LC}$ patient's blood obtained CTP A score of 34 patients $(57 \%)$, CTP B score of 26 patients $(43 \%)$, and none of CTP C score, because patients with CTP C scores received an albumin infusion routinely each week, while albumin administration might affect $\mathrm{Zn}$ serum levels.

The study of Triwikatmani et al (2009) on the association between $\mathrm{Zn}$ serum level and $\mathrm{Zn}$ urine level in 39 LC SH patients obtained CTP A of 2 patients (5.6\%), CTP B of 24 patients (66.7\%) and CTP C of 10 patients (27.8\%) (Triwikatmani C et al., 2009). However, this study did not analyze patients with CTPA scores due to $\mathrm{Zn}$ serum levels of patients with CTP A was normal. The 
Soomro et al (2009) study of Zn serum levels in 127 LC patients has obtained CTP A score of 15 patients (12\%), CTP B of 20 patients (16\%) and CTP C of 92 patients (72\%) (Soomro AA et al., 2009). The study of Maher et al (2013) on hyponatremia and Zn deficiency as a risk factor for encephalopathy in LC with 30 patients obtained CTP A score of 8 patients (26\%), CTP B score of 25 patients $(50 \%)$ and CTP C score of 7 patients (24\%) (Maher M et al., 2013). The various studies have different percentages in each group of CTP score due to differences in clinical features (ascites) and laboratories (bilirubin, albumin, prothrombin time). Thus, it affected the number of patients in each group of CTP score. Besides, this study did not include LC patients with EH stage 1 to 4, because the factors that triggered the occurrence of EH such as bleeding, infection/sepsis, disruption of fluid balance were the exclusion criteria in this study.

Laboratory examination of $\mathrm{Zn}$ serum level obtained a mean of $39.28 \pm 15.33 \mu \mathrm{g} / \mathrm{dl}$. The lowest was $18 \mu \mathrm{g} /$ $\mathrm{dl}$ and the highest was $87 \mu \mathrm{g} / \mathrm{dl}$. The normal level of $\mathrm{Zn}$ serum was $60-120 \mu \mathrm{g} / \mathrm{dl}$. Four patients $(9.3 \%)$ had normal Zn serum levels, while 39 patients $(90.7 \%)$ had less than normal level of $\mathrm{Zn}$ serum. The $\mathrm{Zn}$ serum level of this study for CTP A score was $58.3 \pm 19.6 \mu \mathrm{g} / \mathrm{dl}$, CTP B score was $43.4 \pm 14.6 \mu \mathrm{g} / \mathrm{dl}$ and CTP C score was 31.6 $\pm 10.1 \mu \mathrm{g} / \mathrm{dl}$ with $\mathrm{p}=0.000$ and $\mathrm{r}=-0.583$.

The research of Somi et al (2007) obtained the result of $\mathrm{Zn}$ serum level on CTP A score of $70.49 \pm 3.15 \mu \mathrm{g} / \mathrm{dl}$ and CTP B score of $58.18 \pm 3.35 \mu \mathrm{g} / \mathrm{dl}$ with $\mathrm{p}=0.005$ and $\mathrm{r}=-0.31$ (Somi $\mathrm{MH}$ et al., 2007). These results were slightly different from this study. However, these two studies showed the greater the LC severity based on CTP scores, the lower $\mathrm{Zn}$ serum levels.

The study of Maher et al (2013) obtained the $\mathrm{Zn}$ serum level in CTP A score of $72.62 \pm 2.77 \mu \mathrm{g} / \mathrm{dl}$, CTP B score of $50.32 \pm 3.96 \mu \mathrm{g} / \mathrm{dl}$ and CTP C score of 35.65 $\pm 6.53 \mu \mathrm{g} / \mathrm{dl}$ with $\mathrm{p}=0.000$ and $\mathrm{r}=-0.61$. It showed a significant difference in each group of CTP score (Maher $\mathrm{M}$ et al., 2013). Thus, the research of Maher et al (2013) was similar to this study.

The study of Triwikatmani et al (2009) of 39 LC patients, there was no significant different $(p=0.052)$ between LC patients with CTP B score $(67.68 \pm 21.55$ $\mu \mathrm{g} / \mathrm{dl})$ and patients with CTP C score $(54.04 \pm 32.25$ $\mu \mathrm{g} / \mathrm{dl}$ ) (Triwikatmani $\mathrm{C}$ et al., 2009). This might be due to the difference in the serum $\mathrm{Zn}$ value of the $\mathrm{LC}$ patient in each CTP score which might be affected by the nutritional status, diuretic usage and management provided.

Malnutrition caused changes in the structure and function of the gastrointestinal tract that resulting in malabsorption of nutrients including $\mathrm{Zn}$. In addition, malnutrition caused a decreased production of bile and pancreatic secretion insufficiency required in the nutrient absorption process, thus the nutritional absorption including $\mathrm{Zn}$ would also be impaired.

The use of diuretics and ascites parasynthesis to overcome ascites in LC lead to a decreased in serum $\mathrm{Zn}$ levels because there was a lot of $\mathrm{Zn}$ removal through urine and ascitic fluid. Triwikatmani et al (2009) stated the greater the amount of urine, the lower $\mathrm{Zn}$ serum levels (Triwikatmani C et al., 2009).

Research on the association between the degree of LC severity based on CTP score and serum Zn level in Gastroenterology-Hepatology Unit and Inpatient medicine wards of Dr. Soetomo General Hospital showed a significant correlation. There was a correlation with a negative or opposite direction between the degree of LC severity and serum Zn level with a correlation strength of -0.583 that categorized as a correlation with moderate strength. This meant that the greater the degree of LC severity based on the CTP score, the lower the serum Zn level. Kar et al (2013) reported that decreased $\mathrm{Zn}$ levels in LC were approximately $10 \%-25 \%$ when it was compared LC controls (non-LC patients). The same thing reported by Somi et al (2007) and Maher et al (2013) which stated the more severe the severity of LC, the serum $\mathrm{Zn}$ level would be lower (Somi MH et al., 2007, Maher M et al., 2013).

Iwata et al (2014) study using METAVIR scoring system showed that liver function and the degree of liver degeneration were correlated with low serum $\mathrm{Zn}$ levels. Their study obtained $\mathrm{p}<0.01$ which showed significant differences, where F0/1 $(n=248)$ with serum $\mathrm{Zn}$ level of $71.3 \pm 11.3 \mu \mathrm{g} / \mathrm{dl}, \mathrm{F} 2(\mathrm{n}=92)$ with serum $\mathrm{Zn}$ levels of $68.9 \pm 11.7 \mu \mathrm{g} / \mathrm{d}$, F3 $(\mathrm{n}=127)$ with serum $\mathrm{Zn}$ levels of $66.3 \pm 11.8 \mu \mathrm{g} / \mathrm{dl}$ and F4 $(\mathrm{n}=109)$ with serum $\mathrm{Zn}$ level of $63.9 \pm 15.0 \mu \mathrm{g} / \mathrm{dl}$ (Iwata K et al., 2014).

Triwikatmani et al (2009) showed different results on the correlation between the degree of LC severity based on CTP scores with serum Zn levels (Triwikatmani $\mathrm{C}$ et al., 2009). The results showed that there was no significant difference with $\mathrm{p}=0.052$ between the patients with CTP B score $(67.68 \pm 21.55 \mu \mathrm{g} / \mathrm{dl})$ and patients with CTP C score $(54.04 \pm 32.25 \mu \mathrm{g} / \mathrm{dl})$.

The limitations of this study were: (1) using a cross sectional design and the degree of LC severity and serum $\mathrm{Zn}$ level was measured together, thus there was a probability of low serum $\mathrm{Zn}$ levels for other reasons before the patient had LC, (2) some of the variables were not carefully studied, such as: malnutrition and diuretic usage, (3) the samples were indistinguishable from the length of LC condition and it was not distinguished the types of treatment obtained, (4) excluding EH due to EH trigger factors (hemorrhage, sepsis, fluid balance disorder), (5) this research was limited to LC patients in the Unit of Gasroentero-Hepatology and inpatient installation of Dr. Soetomo General Hospital, and (6) had limited sample size and length of study time.

\section{CONCLUSION}

The result of the statistical test showed a significant correlation betwen LC severity and $\mathrm{Zn}$ serum level. The havier the severit of LC, the lower Zn serum levels.

\section{CONFLICT OF INTEREST}

The author declare there is no conflict of interest of this study. 


\section{REFERENCES}

Bacon Br 2008. Cirrhosis and its Complications. Harrison's Gastroentrology and Hepatology. 17th Edition Ed. Longo Dl, Fauci As: Mcgraw-Hill Companies.

Blachier, M., Leleu, H., Peck-Radosavljevic, M., Valla, D. C. \& Roudot-Thoraval, F. 2013. The Burden of Liver Disease in Europe: A Review of Available Epidemiological Data. European Association for The Study of The Liver Journal, $58,593-608$.

Durand, F. \& Valla, D. 2005. Assessment of The Prognosis of Cirrhosis: Child-Pugh Versus Meld. Journal of Hepatology, 42 Suppl, S100-7.

Heidelbaugh, J. J. \& Sherbondy, M. 2006. Cirrhosis and Chronic Liver Failure: Part Ii. Complications and Treatment. American Family Physician, 74, 767-76.

Iwata K, Enomoto H, Nishiguchi S, Sato N \& Aiwa N 2014. Serum Zinc Value in Patients with Hepatitis Virus Related Chronic Liver Disease: Association with The Histological degree of Liver Fibrosis and with The Severity of Varices In Compensated Cirrhosis. Journal Clinical Biochem Nutrition, 2, $147-152$.
Kusumobroto Ho 2012. Sirosis Hati. In: Ha, S., Hn, A. \& La, L. (Eds.) Buku Ajar Ilmu Penyakit Hati. Jakarta: Cv Sagung Seto.

Maher M, Tarek M, Yosef A \& Alkady H 2013. Hyponatremia and Zinc Deficiency as a Risk Factor for Hepatic Encephalopathy in Cirrhotic Patients. Life Science Journal, 10, 3-10.

Nurdjanah S 2009. Sirosis Hati. In: Sudoyo Wa, Setiyohadi B, Alwi I, Simadibrata M \& Setiati S (Eds.) Buku Ajar Ilmu Penyakit Dalam Jakarta Pusat Penerbitan Departemen Ilmu Penyakit Dalam Fk - UI.

Somi Mh, Rahimi Ao \& Rezaeifar P 2007. Nutritional Status and Blood Trace Elements in Cirrhotic Patients. Hepatitis Mouthly, , 7, 27-32.

Soomro Aa, Devrajani Br \& Shaikh K 2009. Serum Zinc Level in Patient with Liver Cirrhosis. Pakistan Journal Medicine Science, 5, 16-26.

Triwikatmani C, Bayupurnama P \& Maduseno S 2009. Serum Zinc Level and Urinary Zinc Excretion In Patient with Liver Cirrhosis. The Indonesian Journal of Gastroenterology, Hepatology and Digestive Endoscopy, 4, 305-311. 